\title{
Distal Technologies Impact, Telehealth and Mhealth, on Type 1 Diabetes Self-Management: A Narrative Review
}

\author{
Letizia Gentilini ${ }^{1}$, Alessandra De Remigis ${ }^{2}$, Ivan Rubbi ${ }^{3}$, Teresa Ambrosini ${ }^{1}$ and Valeria Cremonini ${ }^{3}$ \\ ${ }^{1}$ School of Nursing, University of Bologna, Italy \\ ${ }^{2}$ Ravenna Internal Medicine Department, Romagna Local Health Authority, Italy \\ ${ }^{3}$ School of Nursing, Romagna Local Health Authority and University of Bologna, Italy
}

Submission: July 25, 2019; Published: August 14, 2019

*Corresponding author: Letizia Gentilini, School of Nursing, Romagna Local Health Authority and University of Bologna, Bologna, Italy

Abstract

Aim: Evaluate possible influences of new technologies on quality of life, disease and its complications management (self-management) in children, teenagers and young adults with type 1 diabetes mellitus.

Research Design: Narrative review

Materials and Methods: In our study we performed a research through scientific/medical database: PubMed, Cinahl, The Cochrane Library, Proquest Central, PhychINFO and UpToDate. As filters we have applied: studies in humans, English language and most recent publication (from 2007 to 2017). Only those responding to the following selection criteria have been selected: 1. Quantitative studies, 2. Use of quantitative evaluation tools, monitoring quality of life and self- management, 3. Reference population of age group less than 65 years old, 4 .Focus on usefulness, satisfaction and technologies influence on quality of life and disease self-management of those affected by type 1 diabetes mellitus (outcomes).

Results: 7 articles were selected. Despite some studies did not show significant differences in quality of life with new technologies use, results showed mostly a significant improvement in young adult patients' glycemic control, affected by type 1 diabetes mellitus, limiting medicalcare timing and costs.

Conclusion: The different studies showed the feasibility of using new apps on mobile technologies, effective mostly in teenagers for chronic disease management, demonstrating how use of new tools is associated with increasing frequency in Self-Monitoring Blood Glucose (SMBG) and improved metabolic control. Therefore, identifying new effective and acceptable technologies is useful to enhance care adherence and impact on quality of life.

Keywords: Type 1 diabetes mellitus; Self-management; Self-monitoring of blood glucose; Mobile technologies; Telemedicine; Quality of life; Chronic disease; Insulin bolus; Diabetes mellitus

Abbrevations: QOL: Quality Of Life; DSQOLS: Diabetes Specific Quality of Life Scale; DQOL-Y: Diabetes Quality of Life for Youth; SDSCA: Summary of Diabetes Self-Care Activities; PAID: Problem Areas in Diabetes Questionnaire; WHO-DTSQ: World Health Organization-Diabetes Treatment Satisfaction Questionnaire; DES-SF: Diabetes Empowerment Questionnaire; SMBG: Self-Monitoring Blood Glucose

\section{Background}

Type 1 diabetes mellitus is the most common and severe childhood metabolic disorder. Its incidence is constantly increasing all over the world [1]. Diabetes is a complex chronic disease that can result in serious acute and chronic complications. The adherence to SMBG in the contest of disease self-management can be very complex and demanding mostly for children and teenagers [2]. Since adolescence is considered age of transition and very difficult time in life, according to Di Bartolo \& coauthors [3], it is essential to promote therapeutic education through modern communication systems and to motivate young populations in employing technologies to self- manage diabetes.

Specific communication systems in the field of diabetes are becoming more and more refined and, as part of "Telemedicine" programs, they allow patients and physicians to transmit data and 
messages related to therapeutic advice, underlining new technologies advantages in treatment, self-management and quality of life in young patients affected by type 1 diabetes [3].

New smartphone, thanks to applications as insulin bolus calculator and blood glucose measurer, can help children and teenagers affected by type 1 diabetes in complex insulin regulation and self- management. Even though more accurate studies are needed, mobile technologies have the potential to improve both self-care and quality of life [2].

New communication modalities are entering the daily routine and are increasingly used as educational systems for patients affected by chronic disease. Sometimes these tools have become even more important and useful than direct contact, because they allow to interact with people, for example teenagers, who otherwise have adopted refusal attitudes and denial about rules. Therefore, it is pivotal to know and examine all technological innovations in order to apply the most suitable one to a specific patient and context [3] Technologies impact on quality of life has to be also considered, in fact it is an increasingly recognized variable that affects psychosocial health in young patients affected by type 1 diabetes mellitus [1].

Diabetes management is an application area where mobile devices could improve quality of life for people living with chronic diseases [4]. Mobile phone usage can potentially help diabetes daily management through creation of an active interaction between patients and healthcare professionals [5].

Compared to the first mobile phones, today smartphones and tablet PC offer a wide range of functions. In medicine, mobile applications support disease management, promoting health and well-being awareness [6].

Arnhold's et al. [6] showed that numerous applications are available to help patient in type 1 and type 2 diabetes mellitus management, due to the increasing prevalence. In fact, the number of health-related applications increased to 31.000 in 2013. Some studies present a diabetes mobile applications in-depth analysis, which shows in the first place that personalized education is only in some applications [4].

Therefore, despite the considerable amount of diabetes mobile applications currently available, most of these offer a limited number of similar features. In fact, it is increasingly difficult for users to find an application that suits their needs [6]. The ideal one would be a multifunctional application that could simultaneously inform and contribute to treatment through documentation, reminder and counseling functions, so that recently diagnosed patients affected by type 1 diabetes would benefit from it. In addition, patients and healthcare providers should be directly involved during the application development to address practical usage, revealing issue needs for their diabetic followers [6].

Another factor highlighted by Baron's et al. [7] study is the importance of remote recording and monitoring data between patient and healthcare workers, also called mobile telemonitoring (mobile Health). Due to the important development of mobile devices and wireless technologies, patients could transmit real time data, at anytime and anywhere promoting a treatment method particularly important for chronic diseases management, that require an intensive daily monitoring [6].

Many studies affirm that values measured in real time automatic transmission from the measuring device to mobile device is an important driver to promote ease of use [6]. They also discuss that some manufacturers already offer glucose meters that allow blood glucose values measured in real time transmission via Bluetooth to a mobile device, simplifying documentation process for the patient and at the same time increasing reliability of the entered data and the subsequent analysis. Wireless technology use in health care has been primarily evaluated as a telemedicine tool and patient orientation is still under development [8].

These new monitoring methods (such as applications or website that help monitor food intake, glucose levels, controls and other significant parameters) in type 1 diabetes management have been well accepted ensuring good decision-making processes, efficiency and adhesion to treatment [9].

Gimènez-Perez's et al. [8] study assessed how the use of internet affects knowledge and well- being of the patient, which state that internet advent will probably change the way healthcare will be carried out. Currently its impact is particularly compromised by access rate and internet use for health purpose, but due to their high rate of ownership and use, mobile phones will be an important promise as a tool in health communication technologies. Among the many studies examined, in this regard, Liang's et al. [5] meta-analysis has shown that mobile phone intervention methods for diabetes treatment have led to significant improvements in glycemic control and self- management. Mobile devices use, data recording and monitoring could be the key factor to increase awareness and motivation of patients to manage themselves [7]. In this regard, Guo's et al. [1] study demonstrates that self-management can positively influence metabolic control and quality of life.

Self-management support provided by nurses has the potential to improve health outcomes in young people affected by type 1 diabetes. The latter take responsibility to be health educators and provide self-management support, a very important role in helping young people achieve better and more effective treatment plans [1].

The aim of this paper is to assess whether new technologies affect quality of life and disease management (self-management) and its complications in children, teenagers and young adults affected by type 1 diabetes mellitus.

\section{Materials and Methods}

Our research was conducted via PICO method and the use of predefined and specific keywords within the databases. During 


\section{Current Research in Diabetes \& Obesity Journal}

the research, abbreviations related to the topic were considered, such as SMBG (Self-monitoring blood glucose), HbA1c (hemoglobin glycated), Telemedicine and mHealth (Mobile Health).

\section{PICO}

a) $\quad$ ( (population) $=$ Patient affected by type 1 diabetes

b) I (intervention) = Technologies evaluation for SMBG and management

c) $\quad$ (comparison $)=$ Traditional care

d) $\mathrm{O}$ (outcomes) $=$ Improvement in self-management and quality of life

\section{Databases research guided by different keywords com- binations identified scientific articles abstracts that were relevant based on:}

i. Comparison between new mobile technologies (smart- phones, tablet, $\mathrm{PC}$, app, software) and glycemic measuring standard method (SMBG)

ii. New technology impact on glycemic monitoring, type 1 diabetes management, chronic disease self-management and quality of life

\section{Articles were selected according to these criteria:}

a. Quantitative studies

b. Use of quantitative tools to evaluate and monitor quality of life and self-management

c. Reference population of age group less than 65 years old

Study focus on utility, satisfaction and technologies influence on quality of life and disease self-management of those affected by type 1 diabetes mellitus (outcomes) (Table 1-3).

Table 1: Studies Selected with Search String:

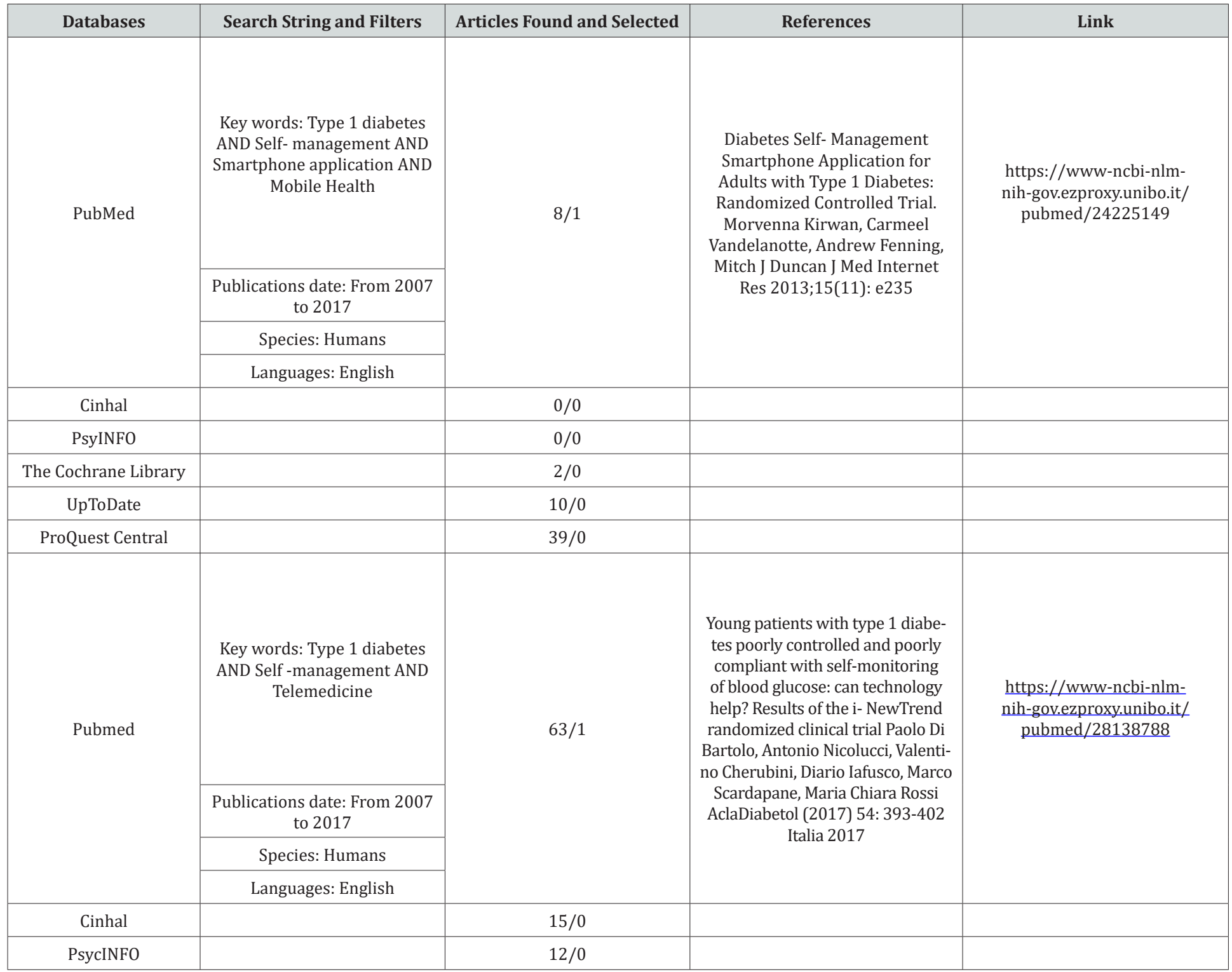




\section{Current Research in Diabetes \& Obesity Journal}

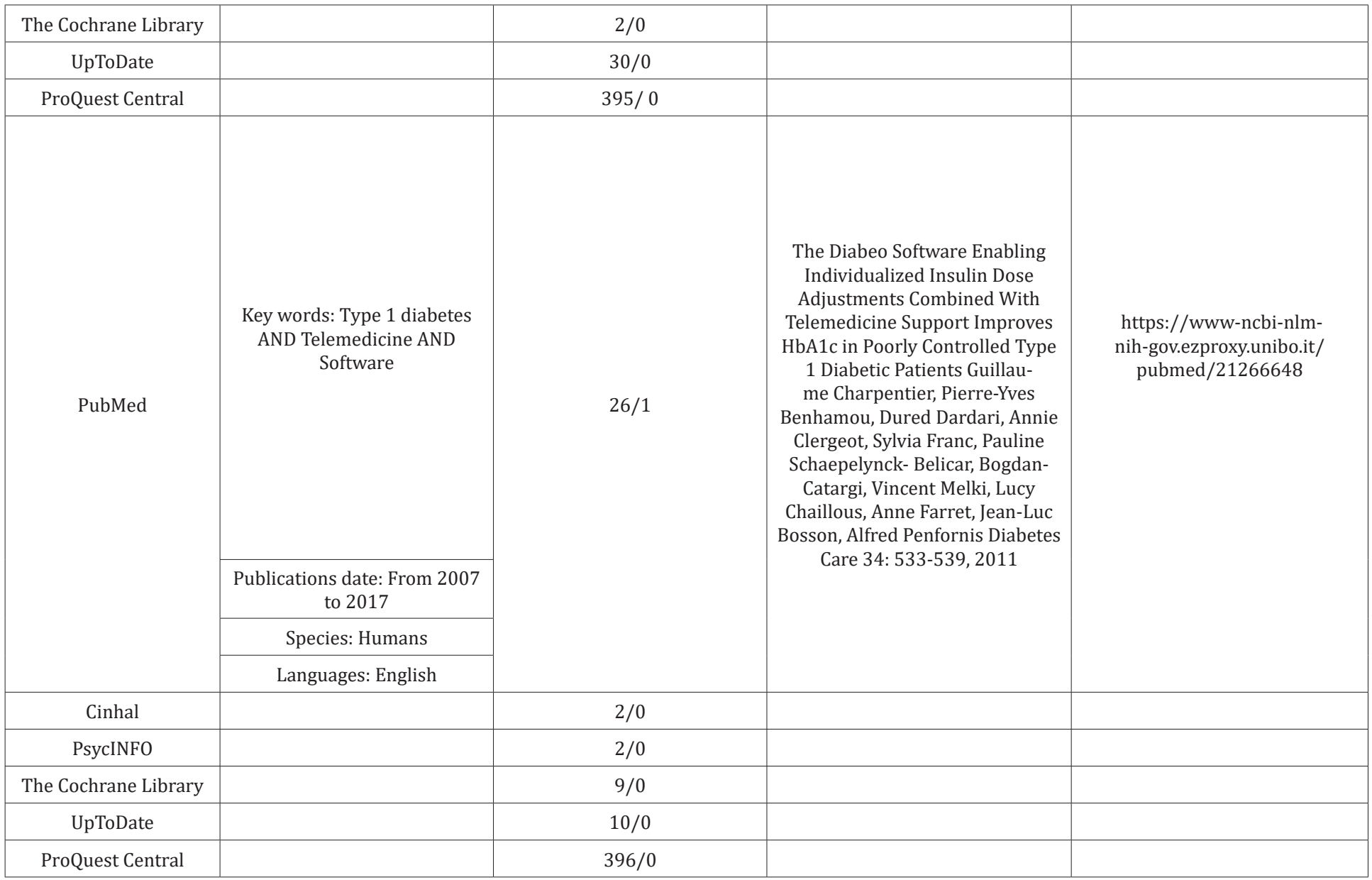

1. Type 1 Diabetes AND Self-Management AND Smartphone Application AND Mobile Health.

2. Type 1 Diabetes AND Self-Management AND Telemedicine

3. Type 1 Diabetes AND Telemedicine AND Software

Table 2: Studies Selected with Search Strings:

\begin{tabular}{|c|c|c|c|c|}
\hline \multirow{3}{*}{ PubMed } & $\begin{array}{l}\text { Key words: Type } 1 \text { diabetes AND } \\
\text { Self- management AND Quality of } \\
\text { life AND Mobile application }\end{array}$ & & \multirow{3}{*}{$\begin{array}{c}\text { The Effects of a Mobile Phone } \\
\text { Application on Quality of Life } \\
\text { in Patients With Type } 1 \text { Dia- } \\
\text { betes Mellitus: A Randomized } \\
\text { Controlled Trial IefkeDrion, } \\
\text { Loes R. Pameijer, Peter R. } \\
\text { van Dijk, Klaas H. Groenier, } \\
\text { NanneKleefstra and Henk J. } \\
\text { G. Bilo Journal of Diabetes } \\
\text { Science and Technology 2015, } \\
\text { Vol. 9(5) 1086-1091 }\end{array}$} & \multirow{3}{*}{$\begin{array}{l}\text { https://www-ncbi-nlm- } \\
\text { nih-gov.ezproxy.unibo.it/ } \\
\text { pubmed/2596341 }\end{array}$} \\
\hline & $\begin{array}{l}\text { Publications date: From } 2007 \\
\text { to } 2017\end{array}$ & & & \\
\hline & Species: Humans & & & \\
\hline Cinhal & & $0 / 0$ & & \\
\hline UpToDate & & $20 / 0$ & & \\
\hline
\end{tabular}




\section{Current Research in Diabetes \& Obesity Journal}

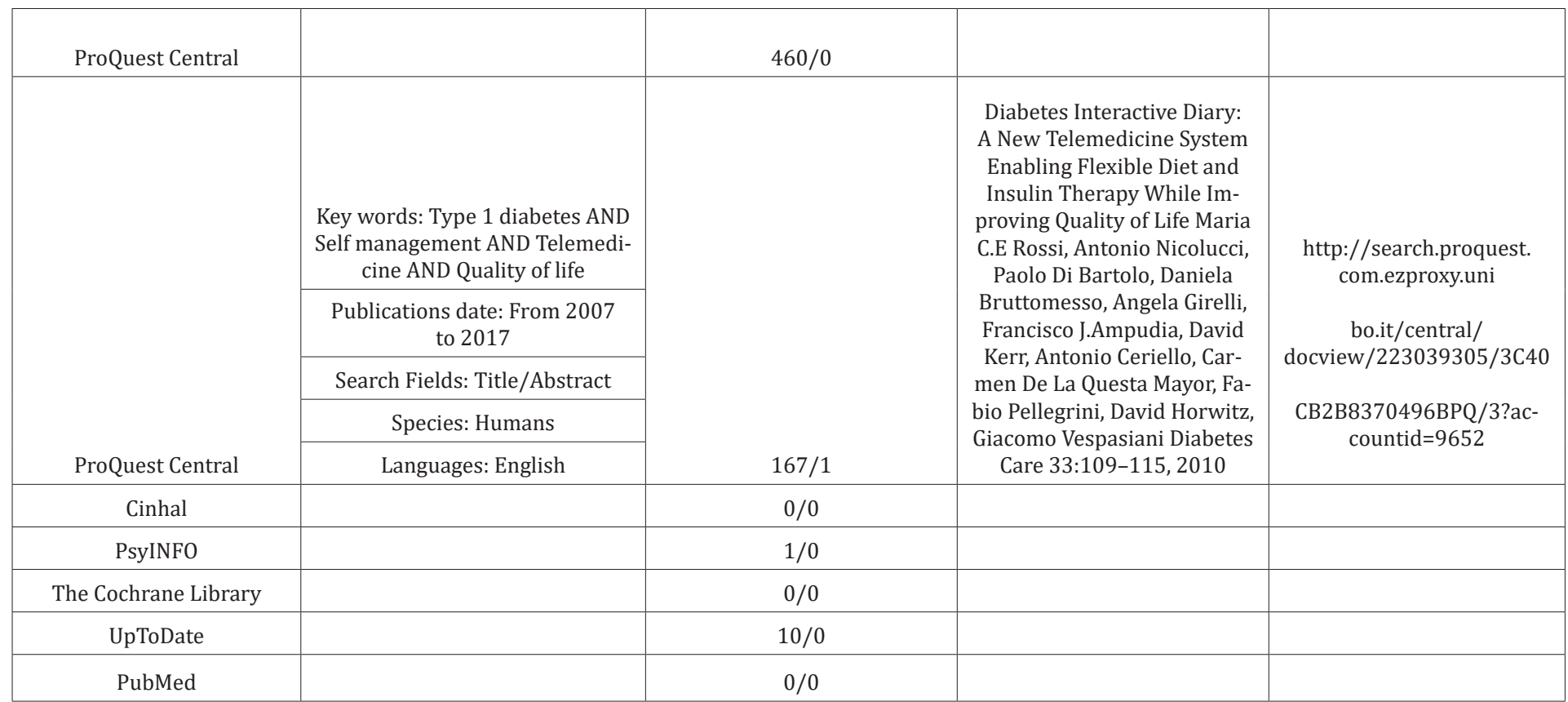

1. Type 1 Diabetes AND Self-Management AND Quality of Life AND Mobile Application

2. Type 1 Diabetes AND Self-Management AND Telemedicine AND Quality of Life

Table 3: Studies Related to Selected Research (References).

\begin{tabular}{|c|c|c|c|c|}
\hline Selected Articles & Search String and Filters & $\begin{array}{l}\text { Articles } \\
\text { Found } \\
\text { and Se- } \\
\text { lected }\end{array}$ & References & Link \\
\hline $\begin{array}{l}\text { Diabetes Self- Management } \\
\text { Smartphone Application for } \\
\text { Adults with Type } 1 \text { Diabetes: } \\
\text { Randomized controlled Trial }\end{array}$ & $\begin{array}{l}\text { Key words: Type } 1 \text { diabetes } \\
\text { AND Self management AND } \\
\text { Smart Phone AND application } \\
\text { And Moblie Health }\end{array}$ & $n^{\circ} 30$ & $\begin{array}{l} \\
\\
\text { Feasibility of a Mobile } \\
\text { Phone-Based Data Service } \\
\text { for Functional term Insulin } \\
\text { treatment of Type } 1 \text { diabetes } \\
\text { Patients. Alexander Kollmann, } \\
\text { Michaela Riedl, Peter Kastner, } \\
\text { Guenter Schreier, Bernard } \\
\text { Ludvik J Med Internet Res } \\
\text { 2007;9(5):e36 }\end{array}$ & $\begin{array}{c}\text { https://www-ncbi-nlm-nih-gov. } \\
\text { ezproxy.unibo.it/pubmed/?term=- } \\
\text { Feasibility\%2Bof\%2Ba\%2BMo- } \\
\text { bile\%2BPhone\%E2\%80\%93Based\%2B- } \\
\text { Data\%2BService\%2Bfor\%2BFunction- } \\
\text { al\%2BInsulin\%2BTreatment\%2Bof\%2B- } \\
\text { Type\%2B1\%2BDiabetes\%2BMellitus\%2B- } \\
\text { Patients }\end{array}$ \\
\hline \multirow[t]{4}{*}{$\begin{array}{l}\text { MorvennaKirwa Publications } \\
\text { n, Carmeel Vandel anotte, } \\
\text { Andrew Fenning, Mitch J } \\
\text { Duncan J Med Internet Res } \\
\text { 2013;15(11):e2 } 35\end{array}$} & $\begin{array}{c}\text { Publications date: From } 2007 \\
\text { to } 2017\end{array}$ & \multirow[t]{3}{*}{$n^{\circ} 20$} & \multirow{4}{*}{$\begin{array}{l}\text { Design of an mHealth App } \\
\text { for the Self- management of } \\
\text { Adolescent Type } 1 \text { Diabetes:A } \\
\text { Pilot Study. Joseph A Cafazzo, } \\
\text { Mark Casselman, Nathaniel } \\
\text { Hamming, Debra K, Katzman, } \\
\text { Mark R Palmert J Med Inter- } \\
\text { net Res 2012;14(3):e70 }\end{array}$} & \multirow[t]{4}{*}{$\begin{array}{l}\text { http://web.a.ebscohost.com.ezproxy. } \\
\text { unibo.it/ehost/detail/detail?sid=1f1b8 } \\
\text { f38-4fa1-431a-9104-6fbe54796502\%- } \\
\text { 40sessionmgr4009\&amp;vid=0\&amp;hi } \\
\text { d=4212\&amp;bdata=Jmxhbmc9aXQmc- } \\
\text { 2l0ZT1laG9zdC1saXZlJnNjb3BlPXNpdGU- } \\
\text { \%3D\%23AN\%3D104488871\&amp;db=ccm }\end{array}$} \\
\hline & Search Fields: Title/Abstract & & & \\
\hline & Species: Humans & & & \\
\hline & Languages: English & & & \\
\hline
\end{tabular}

It Shows Selected Articles among the Mentioned Bibliography of Kirwan's et al. [15] article. 


\section{Current Research in Diabetes \& Obesity Journal}

\section{Results}

Technology impact on glycemic control and quality of life has been studied in different parts of the world because diabetes as a chronic disease is increasingly widespread nowadays. Studies dealing with the use of new technologies in helping the disease management and their influence on quality of life are mainly carried out in Europe (Italy and France), America (Canada) and Australia. In particular, 5 out of 7 are RCT (randomized controlled trials) and the remaining 2 are pilot studies.

The different studies have been published over the years, from 2007 until the early months of 2017. We have selected articles from these journals: J Med Internet Res (3 studies), Diabetes Care (2 studies), Acta Diabetol and the Journal of Diabetes Science and Technology with one article respectively. All the articles taken into consideration show defined research design (RCT) that allows to evaluate how new technological systems use, compared with traditional glycemic control in 5 studies, influence children, teenagers and young adults self-monitoring, compliance and quality of life. The remaining two are pilot studies. Sample size examined is not homogeneous among the different selected studies, ranging from a minimum of 10 patients [10] to a maximum of 182 patients [11]. With regard to patients type, only young patients under 65 years old affected by type 1 diabetes were taken into consideration, including adolescents.
Outcomes evaluation times differ among each study: from an outcome's evaluation after 12 weeks [12] to an evaluation after 18 months [11].

Technologies examined are quite heterogeneous among the different studies, ranging from telemedicine such as smartphones, software, telephones applications for glycemic monitoring values to new monitoring systems. Evaluation scales used to examine impact on self-management and quality of life are DES-SF (Diabetes Empowerment Questionnaire), WHO-DTSQ (World Health Organization-Diabetes Treatment Satisfaction Questionnaire), PAID (Problem Areas in Diabetes questionnaire), SDSCA (the Summary of Diabetes Self-Care Activities), SF-36 health surgery, RAND-36 health surgery, DQOL (Diabetes Quality of Life), DQOL-Y (Diabetes Quality of Life for Youth), Add QOL (Audit of diabetes-dependent Quality of Life) and DSQOLS (Diabetes Specific Quality of Life Scale).

\section{Summarized outcomes are:}

a) Mobile and non-mobile technologies utility for type 1 diabetes monitoring and management

b) Influence on quality of life and satisfaction in treatment and/ or in device

c) Glycemic values improvement such as HbA1c (Table 4).

Table 4: Detailed description of each study.

\begin{tabular}{|c|c|c|c|c|c|c|c|c|}
\hline Study & $\begin{array}{l}\text { Study } \\
\text { Type }\end{array}$ & Purpose & $\begin{array}{l}\mathrm{N}^{\circ} \text { Partici- } \\
\text { pants }\end{array}$ & $\begin{array}{c}\text { Evaluation } \\
\text { Time and } \\
\text { Outcomes }\end{array}$ & Primaryaim & Secondaryaim & $\begin{array}{l}\text { Quantitative } \\
\text { Tools }\end{array}$ & $\begin{array}{c}\text { Technological- } \\
\text { tools }\end{array}$ \\
\hline $\begin{array}{l}\text { Di Bartolo et al. } \\
\text { (2017) }\end{array}$ & RCT & $\begin{array}{l}\text { Compare new tele- } \\
\text { medic ine system } \\
\text { called iBGStar } \\
\text { and DMApp with } \\
\text { traditional glycemic } \\
\text { control in teenager } \\
\text { s and young adult } \\
\text { affected by type } 1 \\
\text { diabetes. }\end{array}$ & $\begin{array}{l}92 \text { group A (iB- } \\
\text { GStar system) } \\
+90 \text { control } \\
\text { group } 182 \\
\text { totals }\end{array}$ & $\begin{array}{l}\text { 3-6 months } \\
\text { experime ntal } \\
\text { phase and } 12 \\
\text { months post- } \\
\text { trial observati } \\
\text { onal phase }\end{array}$ & $\begin{array}{l}\text { Evaluat how te- } \\
\text { lemedici ne sy- } \\
\text { stem influences } \\
\text { self- monito- } \\
\text { ring measuring } \\
\text { and analyzing } \\
\text { HbA1C value }\end{array}$ & $\begin{array}{l}\text { Evaluate this } \\
\text { technology } \\
\text { influence in } \\
\text { compliance and } \\
\text { quality of life. }\end{array}$ & $\begin{array}{l}\text { 1. Audit of } \\
\text { Diabetes- de- } \\
\text { pendent quality } \\
\text { of life (ADDQol) } \\
\text { 2. Diabetes } \\
\text { Quality of Life } \\
\text { (DQOL) } \\
\text { 3. Visual } \\
\text { analogue scale } \\
\text { (VAS) }\end{array}$ & $\begin{array}{l}\text { 1.iBGStar } \\
\text { telemedicine } \\
\text { system }\end{array}$ \\
\hline $\begin{array}{l}\text { Drion et al. } \\
\text { (2015) }\end{array}$ & RCT & $\begin{array}{l}\text { Investigat e the use } \\
\text { of mobile applicatio } \\
\mathrm{n} \text { (DBEES) as a dia- } \\
\text { betes digital diary in } \\
\text { patients affected by } \\
\text { type } 1 \text { diabetes with } \\
\text { traditional paper } \\
\text { diary. }\end{array}$ & $\begin{array}{c}31 \text { intervention } \\
\text { group (digital } \\
\text { diary uses } \\
\text { DBEES) + } 32 \\
\text { control group } \\
\text { (paper diary) }\end{array}$ & 3 months & $\begin{array}{l}\text { Evaluatetw o } \\
\text { carbohydra } \\
\text { tes calcula- } \\
\text { tion methods } \\
\text { influence on } \\
\text { quality of life. }\end{array}$ & $\begin{array}{l}\text { Evaluate mo- } \\
\text { bile applica- } \\
\text { tion usability, } \\
\text { HbA1c values, } \\
\text { self-monitoring } \\
\text { frequency. }\end{array}$ & $\begin{array}{l}\text { 1. RAND-36 } \\
\text { health survery } \\
\text { 2. Problem Are- } \\
\text { as in Diabetes } \\
\text { questionnaire } \\
\text { (PAID) } \\
\text { 3. SUS for appli- } \\
\text { cation usability } \\
\text { evaluation }\end{array}$ & $\begin{array}{c}\text { 1. DBEES } \\
\text { mobile phone } \\
\text { application as a } \\
\text { diabetes diary }\end{array}$ \\
\hline $\begin{array}{l}\text { Kirwan et al. } \\
\text { (2013) }\end{array}$ & RCT & $\begin{array}{l}\text { Examine the effecti- } \\
\text { ven ess of a smar- } \\
\text { tpho ne applicatio } \\
\text { n freely available in } \\
\text { combinati on with a } \\
\text { feedback system of } \\
\text { text message sent by } \\
\text { an expert (diabetes } \\
\text { certified educator) } \\
\text { in young patients } \\
\text { affected by type } 1 \\
\text { diabetes. }\end{array}$ & $\begin{array}{l}36 \text { intervention } \\
\text { group (smar- } \\
\text { tphone applica- } \\
\text { tion use) + } 36 \\
\text { control group } \\
\text { (glucometer } \\
\text { use) }\end{array}$ & $\begin{array}{c}9 \text { months, regu- } \\
\text { lar SMBG every } \\
3 \text { months }\end{array}$ & $\begin{array}{l}\text { Evaluate HbA1c } \\
\text { levels variation } \\
\text { following a } \\
\text { glycemic con- } \\
\text { trol increase }\end{array}$ & $\begin{array}{l}\text { Evaluate self- } \\
\text { efficacy related } \\
\text { to diabetes } \\
\text { management, } \\
\text { activity and } \\
\text { self-care, quali- } \\
\text { ty of life. }\end{array}$ & $\begin{array}{l}\text { 1. Diabetes-re- } \\
\text { lated psychoso- } \\
\text { cial self- effica- } \\
\text { cy (DES-SF) } \\
\text { 2. Summary of } \\
\text { Diabetes Self- } \\
\text { care Activities } \\
\text { (SDSCA) } \\
\text { 3. Diabetes } \\
\text { quality of life } \\
\text { (DQOL) }\end{array}$ & $\begin{array}{l}\text { 1. Glucose Bud- } \\
\text { dysmartphone- } \\
\text { app lication }\end{array}$ \\
\hline
\end{tabular}




\section{Current Research in Diabetes \& Obesity Journal}

\begin{tabular}{|c|c|c|c|c|c|c|c|c|}
\hline $\begin{array}{l}\text { Cafazz o et al. } \\
\text { (2012) }\end{array}$ & Pilotstudy & $\begin{array}{l}\text { Design and develop } \\
\text { a mHealth (mo- } \\
\text { bile health) pilot } \\
\text { intervention for type } \\
1 \text { diabetes mana- } \\
\text { gement in teenager } \\
\text { s using mobile } \\
\text { applications applied } \\
\text { to iPhone phones } \\
\text { thanks to a glucomet } \\
\text { er fitted with a Blue- } \\
\text { tooth adapter }\end{array}$ & $\begin{array}{l}\text { 20totalsa- } \\
\text { gedbetwe- } \\
\text { en } 12-16 \text { yo }\end{array}$ & 12 weeks & $\begin{array}{l}\text { Daily average } \\
\text { frequency } \\
\text { evaluation of } \\
\text { measurements } \\
\text { and glucose va- } \\
\text { lues and HbA1c } \\
\text { variations } \\
\text { through mobile } \\
\text { phone or ipod } \\
\text { touch use }\end{array}$ & $\begin{array}{l}\text { Evaluation of } \\
\text { self-efficacy } \\
\text { and adheren- } \\
\text { ce to treat- } \\
\text { ment, quality of } \\
\text { life and family } \\
\text { responsibility } \\
\text { in diabetes } \\
\text { management }\end{array}$ & $\begin{array}{l}\text { 1. Self-care } \\
\text { Inventory } \\
\text { (Self-care 14) } \\
\text { 2. Diabetes Fa- } \\
\text { mily Responsi- } \\
\text { bility Question- } \\
\text { naire } \\
\text { 3. Diabetes } \\
\text { Quality of } \\
\text { life for youth } \\
\text { (DQOL-Y) }\end{array}$ & $\begin{array}{c}\text { 1. Mobile } \\
\text { application } \\
\text { associated to } \\
\text { a LifeScan glu- } \\
\text { cometer with } \\
\text { a Bluetooth } \\
\text { adapter }\end{array}$ \\
\hline $\begin{array}{l}\text { Guillau me et } \\
\text { al. (2011) }\end{array}$ & RCT & $\begin{array}{l}\text { Demonstr ate that } \\
\text { Diabeo software } \\
\text { can calculate the } \\
\text { right dose of insulin } \\
\text { bolus, supporte d } \\
\text { by a telemedic ine } \\
\text { system, significan tly } \\
\text { improving HbA1C } \\
\text { values in poorly } \\
\text { controlled type } 1 \\
\text { diabetic patients }\end{array}$ & $\begin{array}{l}61 \text { group } \mathrm{G} 1+ \\
60 \text { group } \mathrm{G} 2 \\
+59 \text { group } \mathrm{G} 3 \\
180 \text { totals with } \\
\text { age }>18 \text { yo }\end{array}$ & $\begin{array}{l}17 \text { months with } \\
\text { basal SMBG } \\
\text { every } 3 \text { months } \\
\text { and at the } \\
\text { study end }\end{array}$ & $\begin{array}{c}\text { Evaluate HbA1c } \\
\text { value varia- } \\
\text { tions }\end{array}$ & $\begin{array}{l}\text { Evaluate chan- } \\
\text { ge in glycemic } \\
\text { monitoring } \\
\text { frequency } \\
\text { (SMBG), in } \\
\text { quality of life } \\
\text { changes and sa- } \\
\text { tisfaction time } \\
\text { spent in visits } \\
\text { or telecommu- } \\
\text { nica tions }\end{array}$ & $\begin{array}{c}\text { 1. Diabetes } \\
\text { quality of life } \\
\text { (DQOL) } \\
\text { 2. Diabetes } \\
\text { health profile } \\
\text { questionnaire }\end{array}$ & $\begin{array}{l}\text { 1. Software } \\
\text { called Diabeo } \\
\text { installed in } \\
\text { smartphone, } \\
\text { insulin bolus } \\
\text { automatic cal- } \\
\text { culator which } \\
\text { data are direct- } \\
\text { ly transmit to } \\
\text { the doctor }\end{array}$ \\
\hline $\begin{array}{l}\text { Rossi et al. } \\
\text { (2010) }\end{array}$ & RCT & $\begin{array}{c}\text { Compare diabetes } \\
\text { interactiv e diary } \\
\text { (DID) use and stan- } \\
\text { dard carbohyd rate } \\
\text { count }\end{array}$ & $\begin{array}{l}67 \text { intervention } \\
\text { group (DID } \\
\text { use) }+63 \text { con- } \\
\text { trol group } \\
130 \text { totals with } \\
\text { age }>18 \text { yo }\end{array}$ & 6 months & $\begin{array}{l}\text { Evaluate DID } \\
\text { use in glyce- } \\
\text { mic control } \\
\text { improveme } \\
\text { nt in shorter } \\
\text { time and easier } \\
\text { approach than } \\
\text { carbohydra te } \\
\text { counting stan- } \\
\text { dard method }\end{array}$ & $\begin{array}{l}\text { Changes in } \\
\text { fasting glucose } \\
\text { levels (FBG), } \\
\text { body weight, } \\
\text { lipidic profile, } \\
\text { blood pressure } \\
\text { and quality of } \\
\text { life evaluation } \\
\text { treatment } \\
\text { satisfaction }\end{array}$ & $\begin{array}{l}\text { 1. Health Sur- } \\
\text { verySF- } 36 \\
\text { 2. World Health } \\
\text { Organization } \\
\text { - Diabetes } \\
\text { Traetment } \\
\text { Satisfaction } \\
\text { Questionnaire } \\
\text { (WHO- DTSQ) }\end{array}$ & $\begin{array}{l}\text { 1. DID inte- } \\
\text { ractive diary } \\
\text { carbohydrate- } \\
\text { bolus insulin } \\
\text { automatic } \\
\text { calculator to } \\
\text { install in tele- } \\
\text { phone }\end{array}$ \\
\hline $\begin{array}{l}\text { Kollma nn et al. } \\
\qquad \text { (2007) }\end{array}$ & Pilotstu dy & $\begin{array}{l}\text { Evaluate the feasibi- } \\
\text { lity and user accep- } \\
\text { tan ce of a mobile } \\
\text { service able to assist } \\
\text { patients in intensive } \\
\text { insulin DM1 treat- } \\
\text { ment reporting data } \\
\text { to a web portal }\end{array}$ & $\begin{array}{l}10 \text { totals aged } \\
\text { between } 18-80 \\
\text { yo affected by } \\
\text { type } 1 \text { diabetes }\end{array}$ & 3 months & $\begin{array}{l}\text { Record as many } \\
\text { possible logins } \\
\text { showing a high } \\
\text { acceptanc e } \\
\text { rate and a use } \\
\text { with positive } \\
\text { feedbacks }\end{array}$ & $\begin{array}{c}\text { Evaluate new } \\
\text { data collection } \\
\text { device use } \\
\text { monitoring } \\
\text { HbA1C }\end{array}$ & $\begin{array}{c}\text { 1.Device } \\
\text { satisfaction } \\
\text { evaluatio nque- } \\
\text { stionnaire }\end{array}$ & $\begin{array}{l}\text { 1. Software ap- } \\
\text { plication called } \\
\text { Diab-Memory }\end{array}$ \\
\hline
\end{tabular}

\section{Discussion}

Use of new technologies influences quality of life and disease management in adolescents and young adults affected by type 1 diabetes mellitus.

Over time technologies have increasingly evolved, improved and integrated in patients' treatment plans. Despite the lack of large studies, results indicate a positive trend on chronic disease self- management and glycemic control, without highlighting any significant quality of life variation.

The analysis encompassed a period of ten years, from 2007 [10] to 2017 [11], from simple reminder software to a self-management tool and then up to sophisticated automatic calculator software of carbohydrate and insulin bolus (Diabeo system [13] and DID system [14]).

Mobile phone and wireless technology become absolute protagonist since 2007 thanks to mobile Diab-Memory application [10], then evolved and improved in the following years through new mobile applications integration providing more individualized health assistance.

Communication technology, also called telemedicine, allows to monitor and transmit in real time blood glucose values and increases contact frequency and direct exchange between patients and healthcare professionals.

Among the seven selected articles, Kirwan et al. highlighted smartphone potential through applications as Glucose Buddy, which uses a text-message feedback system sent from an expert in order to improve glycemic control and consequently reduce HbA1c values [15].

One of the most relevant studies conducted by an Italian experts' group in 2017 demonstrated how telemedicine systems can encourage teenagers to adhere to treatment using new devices which double daily measurements frequency of glucose values, thereby reducing HbA1c values [11]. Technologically advanced solutions can be an option to motivate patients to regularly check 
blood glucose values, especially for young teenagers particularly inclined to technology. Adolescence represents a peculiar, highly delicate and susceptible time of personal development: teenagers begin to acquire their independence and autonomy from the family, but when the diagnosis approaches, patients show their psychosocial vulnerability, especially at the end of the "honeymoon" period and when treatments become more intense [16]. Family conflicts are very frequent, generated around treatment needs in chronic disease, especially at its onset, thereby interfering with treatment outcomes.

Di Bartolo \& his team [3] conducted their studies in a young population with a propensity towards technology. Adapting to patient needs, they searched the most suitable and requested type of patient communication system, because communication has significant psychosocial and social implications [10]. Teenagers are inclined to request their autonomy and to grow apart from adults, to hide themselves in the internet world where they search for answers, advices and comparisons through web and mobile world; so, it is important to focus on developing great and powerful technologies. Psychosocial impact is significant; it is worth of notice comparing a chat line system and a social network, the latter identified less success assuming that teenagers struggling with diabetes do not intend to show themselves, preferring to remain anonymously in chat line microcosm.

New communication methods are thus used in health field as an educational system promoting direct contact between patients, professionals and peers, not to deny the disease but to know, understand the most appropriate way of treatment regimens and self-management and to promote long-term complications prevention. Young patients are open to the unlimited wireless and mobile world experiencing everything too "automated", with the risk of reducing patient awareness of his/her health condition. For this reason, the innovative system proposed must be always associated with an educational intervention.

Most of the analyzed studies take into account the design and the operativity of mobile applications and software, by comparing them to classical SMBG system and evaluating their impact on $\mathrm{HbA1c}$ values (self-monitoring). Only few studies examine the influence of their use on quality of life and treatment satisfaction.

Among all the analyzed studies, only one [17] established as primary aim how technology influences quality of life, it is necessary to overcome this limit, because quality of life (QOL) improvement is a paramount outcome to evaluate in any study on young populations. In addition, QOL is closely related to depression, disease progression, therapeutic adhesion and consequently to mortality [11]. Further studies are needed, directed to a larger sample with frequent follow-up in a long-term intervention, to demonstrate benefits and harms of using mobile applications on quality of life.

For each researched outcome (utility, satisfaction, influence), most studies showed a positive response on glycemic control, statistically improving $\mathrm{HbA1c}$ values due to increase in therapeutic adhesion. In respect of treatment satisfaction and influence on quality of life, most of telemedicine technologies showed a good treatment satisfaction without underlining specific influences on quality of life. Therefore, impact on quality of life requires further studies with a long-term intervention.

The economic burden remains a significant obstacle to telemedicine system diffusion, due to the fact that proposed devices are not refundable by health insurance.

A meta-analysis was not performed because quantitative tools of monitoring and evaluating quality of life and self-management were not comparable among the considered studies.

Studies duration was variable (from a minimum of 12 weeks to a maximum of 18 months); evaluation of quality of life is a measurable parameter on long-term follow-up; therefore, influence on overall quality of life resulted mostly unchanged.

Telemedicine services support patient in his/her chronic disease self-management. The use of new technological systems, such as mobile applications and software systems, encourages young population affected by type 1 diabetes to adhere to treatments, increase SMBG and monitor the essential values for good disease management such as glucose levels, insulin dosages, related medical aspect, diet type and physical activity. Software applications on mobile phones offer a strong and easy-to-use platform showing a general satisfaction towards innovative treatment, positively affecting quality of life in the long run.

In the last decade, technologies evolved from reminder software to powerful self-management tools such as insulin bolus automatic calculators based on carbohydrates taken values. "DID" system as well as "Diabeo" software are the emblem of the new advanced technologies able to overcome the complex educational requirement and the various difficulties identified in diabetes mellitus management. These devices are successful due to their ability to calculate insulin dose needed in real time, offering constant telemonitoring and immediate transmission of data to medical portal, and the possibility of arranging teleconsultations., Complexity of disease management is reduced, progressively increasing treatment satisfaction, improving some aspects related to quality of life. Thanks to technological systems, direct contact between patients and healthcare providers is improved, reducing healthcare costs.

In the future, more sophisticated mobile applications are needed: for example the "interactive apps", able to analyze data collected in real time supported by automatic feedback and systematic consultations between patients and healthcare professionals overcoming the multitude of electronic logbook applications useful for glycemic values collection, visualization and reading.

We need to research and develop new approaches and optimize those already existing in order to manage chronic disease in a difficult period of life as adolescence. 


\section{Current Research in Diabetes \& Obesity Journal}

Our aim is to improve the actual health costs, identifying young patients willing to replace the classic face-to-face follow-up with new telemedicine approaches.

\section{Conclusions}

Nowadays, smartphones and PCs accompany everyday life and in healthcare they represent a great resource especially in chronic diseases management.

Nonadherence to SMBG is the common problem of young patients affected by type 1 diabetes mellitus that can cause severe cardiovascular, renal, nervous and visual system damage over time.

Blood glucose self-monitoring is considered essential routine in patients affected by type 1 diabetes, it requires frequent SMBG through finger punctures and represents a significant burden in reaching adequate glycemic control.

During adolescence, the intensive self-management required by the disease can put compliance at risk, so it is important to stimulate a therapeutic alliance between young patients and their physicians based on therapeutic and behavioural goals.

Among adolescents, inclination towards new technologies can support them to meet their needs, helping them to improve self-management.

Mobile phone has become the primary communication tool, making it a powerful platform to provide individualized healthcare.

Telemedicine principle, understood as a contemporary information and communication technology, includes different applications and services that use different telecommunication forms such as e- mails, smartphones, wireless tools, web portals etc. becoming an important means to encourage treatment adherence in this patient's group.

The different telemedicine systems used have evolved simplifying self-management process more and more, making available data and graphs in real time and everywhere, promoting the close collaboration between patients and healthcare professionals thanks to direct feedback systems.

Finally, we can conclude that, although some studies do not show significant differences in quality of life, results indicate a significant improvement in young adult patients affected by type 1 diabetes glycemic control without requiring constant physician presence and with overall lower costs than usual care. Telemedicine use positively influences treatment satisfaction, suggesting the increase in acceptance levels to the complex therapeutic plan required by chronic disease management. Different studies show the feasibility of using mobile applications, especially in adolescence, demonstrating how the use of new tools is associated with an increase in glycemic monitoring frequency, improving overall the metabolic control.
Identification of new, effective and acceptable technologies is needed in order to improve adherence to diabetes care and ameliorate quality of life of patients with type 1 diabetes. Smartphone role moves to diabetes care.

\section{Key Points}

New communication methods associated with mobile phones use are dedicated to a young population particularly inclined to new technologies. They become key factors in patient's awareness of disease status, and motivation in self-management of a complex disease as diabetes, improving overall glycemic control.

\section{References}

1. Guo J, Whittemore R, Jeon S, Grey M, Zhou Z, et al. (2014) Diabetes selfmanagement, depressive symptoms, metabolic control and satisfaction with quality of life over time in Chinese youth with type 1 diabetes. J Clin Nurs 24(9-10): 1258-1268.

2. Masakazu H, Beverly EA, Weinger K (2012) Quality of Life and Technology: Impact on Children and Families with Diabetes. Curr Diab Rep 12(6): 711-720.

3. Di Bartolo P, Gentile S, Grassi G, Iafusco D, Maran A (2010) Nuove tecnologie nella cura del diabete: recenti sviluppi e prospettive future. Pisa: Carlo B. Giorda.

4. Chomutare T, Fernandez-Luque L, Årsand E, Hartvigsen G (2011) Features of Mobile Diabetes Applications: Review of the Literature and Analysis of Current Applications Compared Against Evidence-Based Guidelines. J Med Internet Res 13(3): 65.

5. Liang X, Wang Q, Yang X, Cao J, Chen J, et al. (2011) Effect of mobile phone intervention for diabetes on glycaemic control: a meta-analysis, Diabet Med 28(4): 455-463.

6. Arnhold M, Dipl-Soz, Quade M, Kirch W (2014) Mobile Applications for Diabetics: A Systematic Review and Expert-Based Usability Evaluation Considering the Special Requirements of Diabetes Patients Age 50 Years or Older. J Med Internet Res 16(4): 104.

7. Baron J, McBain H, Newman S (2012) The Impact of Mobile Monitoring Technologies on Glycosylated Hemoglobin in Diabetes: A Systematic Review. J Diabetes Sci Technol 6(5): 1185-1196.

8. Giménez-Pérez G, Gallach M, Acera E, Prieto A, Carro O, et al. (2002) Evaluation of Accessibility and Use of New Communication Technologies in Patients with Type 1 Diabetes Mellitus. J Med Internet Res 4(3): 16.

9. Ilies RF, Catana A (2016) Effectiveness of Telemedicine Interventions in the Management of Type 1 Diabetes, Applied Medical Informatics 38: 99-104.

10. Kollman A, Riedi M, Kastne P, Schreier G, Ludvik B (2007) Feasibility of a mobile phone-based data service for functional insulin treatment of type 1 diabetes mellitus patients. J Med Internet Res 9(5): 36.

11. Di Bartolo P, Nicolucci A, Cherubini V, Iafusco D, Scardapane M, et al. (2017) Young patients with type 1 diabetes poorly controlled and poorly compliant with self-monitoring of blood glucose: can technology help? Results of the i-New Trend randomized clinical trial. Acta Diabetol 54(4): 393-402.

12. Cafazzo JA, Casselman M, Hamming N, Katzman D, Palmert MR (2012) Design of an mHealth App for the Self-management of Adolescent Type 1 Diabetes:A Pilot Study. J Med Internet Res 14(3): 70.

13. Charpentier G, Benhamou P, Dardari D, Clergeot A, Franc S, et al. (2011) The Diabeo Software Enabling Individualized Insulin Dose Adjustments Combined with Telemedicine Support Improves HbA1c 


\section{Current Research in Diabetes \& Obesity Journal}

in Poorly Controlled Type 1 Diabetic Patients. Diabetes Care 34(3): 533-539.

14. Rossi MC, Nicolucci A, Di Bartolo P, Bruttomesso D, Girelli A, et al (2010) Diabetes Interactive Diary: A New Telemedicine System Enabling Flexible Diet and Insulin Therapy While Improving Quality of Life. Diabetes Care 33(1): 109-115.

15. Kirwan M, Vandelanotte C, Fenning A, Duncan Mzj (2013) Diabetes Self Management Smartphone Application for Adults with Type 1 Diabetes: Randomized Controlled Trial. J Med Internet Res 15(11): 235.
16. (2016) Standard Italiani per la cura del diabete mellito 2016 , Associazione Medici Diabetologi (AMD), Società Italiana di Diabetologia (SID), giugno.

17. Drion I, Pameijer LR, Van Dijk PR, Groenier KH, Kleefstra N, et al (2015) The Effects of a Mobile Phone Application on Quality of Life in Patients with Type 1 Diabetes Mellitus: A Randomized Controlled Trial. J Diabetes Sci Technol 9(5): 1086-1091.

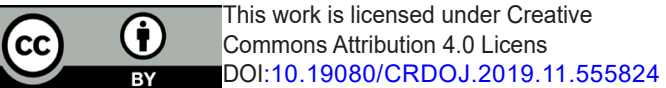

Your next submission with Juniper Publishers
will reach you the below assets
- Quality Editorial service
- Swift Peer Review
- Reprints availability
- E-prints Service
- Manuscript Podcast for convenient understanding
- Global attainment for your research
- Manuscript accessibility in different formats
( Pdf, E-pub, Full Text, Audio)
- Unceasing customer service
Track the below URL for one-step submission
https://juniperpublishers.com/online-submission.php

